\title{
A study of the mechanism of enhancing oil recovery using supercritical carbon dioxide microemulsions
}

\author{
Dong Zhaoxia ${ }^{1,2,3 *}$, Li Yi, ${ }^{1,2}$, Lin Meiqin ${ }^{1,2,3}$ and Li Mingyuan", 2,3 \\ ${ }^{1}$ Enhanced Oil Recovery Research Institute, China University of Petroleum, Beijing 102249, China \\ ${ }^{2}$ Beijing Key Laboratory for Greenhouse Gas Storage and Enhanced Oil Recovery, Beijing 102249, China \\ ${ }^{3}$ Key Laboratory of Enhanced Oil Recovery, CNPC, Beijing, 102249, China
}

(C) China University of Petroleum (Beijing) and Springer-Verlag Berlin Heidelberg 2013

\begin{abstract}
Supercritical carbon dioxide $\left(\mathrm{scCO}_{2}\right)$ microemulsion was formed by supercritical $\mathrm{CO}_{2}$, $\mathrm{H}_{2} \mathrm{O}$, sodium bis(2-ethylhexyl) sulfosuccinate (AOT, surfactant) and $\mathrm{C}_{2} \mathrm{H}_{5} \mathrm{OH}$ (co-surfactant) under pressures higher than $8 \mathrm{MPa}$ at $45^{\circ} \mathrm{C}$. The fundamental characteristics of the $\mathrm{scCO}_{2}$ microemulsion and the minimum miscibility pressure (MMP) with Daqing oil were investigated with a high-pressure falling sphere viscometer, a high-pressure interfacial tension meter, a PVT cell and a slim tube test. The mechanism of the $\mathrm{scCO}_{2}$ microemulsion for enhancing oil recovery is discussed. The results showed that the viscosity and density of the $\mathrm{scCO}_{2}$ microemulsion were higher than those of the $\mathrm{scCO}_{2}$ fluid at the same pressure and temperature. The results of interfacial tension and slim tube tests indicated that the MMP of the $\mathrm{scCO}_{2}$ microemulsion and crude oil was lower than that of the $\mathrm{scCO}_{2}$ and crude oil at $45^{\circ} \mathrm{C}$. It is the combined action of viscosity, density and MMP which made the oil recovery efficiency of the $\mathrm{scCO}_{2}$ microemulsion higher than that of the $\mathrm{scCO}_{2}$ fluid.
\end{abstract}

Key words: Supercritical carbon dioxide, microemulsion, MMP, enhancing oil recovery

\section{Introduction}

Supercritical $\mathrm{CO}_{2}\left(\mathrm{scCO}_{2}\right)$ is one of the environmentally friendly and nontoxic fluids. It has been widely used for many industry processes because of its low critical temperature, moderate critical pressure and low price (Eckert et al, 1996; Yu et al, 2006; Chattopadhyay and Gupta, 2001; Kalogiannis et al, 2005; Kikic et al, 1997; Matson et al, 1987; Zhao et al, 2011).

To realize a win-win situation of enhancing oil recovery and $\mathrm{CO}_{2}$ emission reduction, injection of released $\mathrm{CO}_{2}$ into reservoirs is becoming an important way of beneficial $\mathrm{CO}_{2}$ utilization (Shen and Yang, 2006; Roper et al, 1992; Grigg and Siagian, 1998; Christensen et al, 1998; Langston et al, 2003). There are two types of $\mathrm{CO}_{2}$ flooding: miscible flooding and immiscible flooding. For miscible flooding, there is a stable flooding zone formed, and the microscopic displacement efficiency is higher than $90 \%$. Meanwhile for immiscible flooding, the displacement efficiency is low. Most reservoirs in China are continental depositional ones; the minimum miscibility pressure (MMP) for $\mathrm{CO}_{2}$ flooding is higher than the formation fracture pressure, so miscible flooding cannot be achieved, which results in a low

*Corresponding author. email: dzx@cup.edu.cn

Received September 19, 2012 displacement efficiency. If the MMP may be controlled lower than the formation fracture pressure, $\mathrm{CO}_{2}$ would be miscible with crude oil, and then the displacement efficiency would be significantly improved.

Nowadays, the commonly-used method to decrease MMP is to add hydrocarbon gases into the $\mathrm{CO}_{2}$ (Bon and Sarma, 2005; Yuan et al, 2004). However, this method is difficult to apply in the reservoirs with few hydrocarbon gases. Moreover, the hydrocarbon gases injected into the reservoir may separate from $\mathrm{CO}_{2}$, which makes the MMP of $\mathrm{CO}_{2}$ flooding increase. This means that the miscible flooding cannot be achieved.

The $\mathrm{scCO}_{2}$ reverse microemulsion method is a combination of supercritical technology and microemulsion technology (Liu et al, 2001; Luo et al, 2005; Zielinski et al, 1997; Zhang et al, 2009; Hutton et al, 1999; Heitz et al, 1997; Eastoe et al, 1996). Surfactant molecules are dissolved in the $\mathrm{ScCO}_{2}$ fluid, spontaneously forming nanoscale aggregates in the $\mathrm{scCO}_{2}$ microemulsion is widely used in many industrial processes, such as chemical reaction, extraction and synthesis of nano-particles (Sun et al, 2001; Holmes et al, 1999; Kane et al, 2000; Ohde et al, 2005), but there is no reports about using $\mathrm{scCO}_{2}$ microemulsion for enhancing oil recovery.

For the microemulsion system, $\mathrm{scCO}_{2}$ is the continuous phase and the surfactant molecules are dissolved in the $\mathrm{scCO}_{2}$ fluid which makes it is possible for the microemulsion 
to be miscible with crude oil under relatively low pressure and decrease the MMP of $\mathrm{CO}_{2}$ and crude oil during $\mathrm{CO}_{2}$ flooding. As a result a high efficiency of oil recovery could be obtained. It is known that the critical pressure of $\mathrm{CO}_{2}$ is 7.32 $\mathrm{MPa}$ and the critical temperature is $31.1^{\circ} \mathrm{C}$ ( $\mathrm{Zhu}$ and $\mathrm{Xu}$, 2006). The experimental pressure in this work is higher than $9 \mathrm{MPa}$ at $45^{\circ} \mathrm{C}$, which means that the $\mathrm{CO}_{2}$ is in a supercritical state. The MMP of $\mathrm{scCO}_{2}$ microemulsion and Daqing crude oil is determined by a slim tube test and an interfacial tension meter, and the mechanism of $\mathrm{scCO}_{2}$ microemulsion for enhancing oil recovery is also discussed.

\section{Experimental}

\subsection{Materials and apparatus}

Carbon dioxide (purity $>99.95 \mathrm{wt} \%$ ) was purchased from the Beijing Jinggao Gases Industry Company. Sodium bis(2ethylhexyl) sulfosuccinate (AOT) (purity > 96wt\%) was provided by the ACROS Company, USA. Absolute ethanol $\left(\mathrm{C}_{2} \mathrm{H}_{5} \mathrm{OH}\right)$ was of guaranteed reagent grade. The crude oil was taken from the Daqing Oilfield.

A high-pressure PVT cell and a high-pressure interfacial tension meter were provided by the Sanchez Technologie Company, France. A SYLDJ-2 high-temperature highpressure falling sphere viscometer was made by the China University of Petroleum (East China).

\subsection{Determination of the density of the $\mathrm{scCO}_{2}$ microemulsion}

For the $\mathrm{scCO}_{2}$ microemulsion, the contents of both AOT and $\mathrm{H}_{2} \mathrm{O}$ were quite low, so the effect of AOT and $\mathrm{H}_{2} \mathrm{O}$ on the molar volume of the microemulsion was neglected. The molar percentages of $\mathrm{CO}_{2}$ and $\mathrm{C}_{2} \mathrm{H}_{5} \mathrm{OH}$ in the microemulsion were $86.7 \%$ and $13.3 \%$, respectively in all experiments. The surfactant $\mathrm{AOT}, \mathrm{C}_{2} \mathrm{H}_{5} \mathrm{OH}, \mathrm{H}_{2} \mathrm{O}$ and $\mathrm{CO}_{2}$ were all injected into the PVT cell and the weight of this system was $95.30 \mathrm{~g}$. The pressure of the PVT cell was set at a specified value, then the volume of this system was recorded every $30 \mathrm{~min}$. When the volume had been constant for $60 \mathrm{~min}$ (three successive recordings), the system was considered to have reached equilibrium, and the final volume was then recorded. The same steps were repeated at different pressures. The density values of the $\mathrm{scCO}_{2}$ microemulsion at different pressures were calculated based on the volume data of the system. The experimental temperature was kept at $45^{\circ} \mathrm{C}$.

\subsection{Determination of the viscosity of the $\mathrm{scCO}_{2}$ microemulsion}

The viscosity of the $\mathrm{scCO}_{2}$ microemulsion was measured with a falling sphere viscometer at $45^{\circ} \mathrm{C}$. The viscometer was adapted to measure the viscosity of high-pressure fluids.

\subsection{Determination of minimum miscibility pressure (MMP)}

\subsubsection{Interfacial tension measurement}

The interfacial tension values between the $\mathrm{scCO}_{2}$ microemulsion (and $\mathrm{scCO}_{2}$ ) and crude oil were measured with a high-pressure interfacial tension meter at $45^{\circ} \mathrm{C}$. The MMPs of the $\mathrm{scCO}_{2}$ microemulsion (and $\mathrm{scCO}_{2}$ ) and crude oil were calculated from interfacial tension values.

\subsubsection{Slim tube test}

A slim tube test is commonly used to estimate the MMP of a given injection solvent and reservoir. A schematic diagram of the slim tube test is shown in Fig. 1. The slim tube was a long coiled tube filled with 100 mesh fine sand. The tube was $19 \mathrm{~m}$ long and $6.2 \mathrm{~mm}$ in diameter, with a pore volume of $222.5 \mathrm{~mL}$. The entry of the slim tube was connected to an intermediate container with a piston. The bottom of the container was connected to a constant speed pump. The gas in the intermediate container was pushed into the slim tube by the piston, which was driven by the pump. A backpressure valve was installed at the exit end of the slim tube to control the pressure. The high-pressure parts of the apparatus were kept in a thermostat. A graduated cylinder was used to collect and accurately measure the volume of the crude oil displaced by the injection fluid. The slim tube was cleaned and then dried for 10 hours at $45{ }^{\circ} \mathrm{C}$. After being dried the slim tube was saturated with crude oil. Crude oil was injected at a rate of $0.2 \mathrm{~mL} / \mathrm{min}$. The minimum miscibility pressure of the $\mathrm{scCO}_{2}$ system and crude oil was determined based on the oil recovery. The test was conducted at $45{ }^{\circ} \mathrm{C}$. An amount of AOT (mass percentage $5.03 \times 10^{-3} \%-15.16 \times 10^{-3} \%$ ), $\mathrm{C}_{2} \mathrm{H}_{5} \mathrm{OH}$

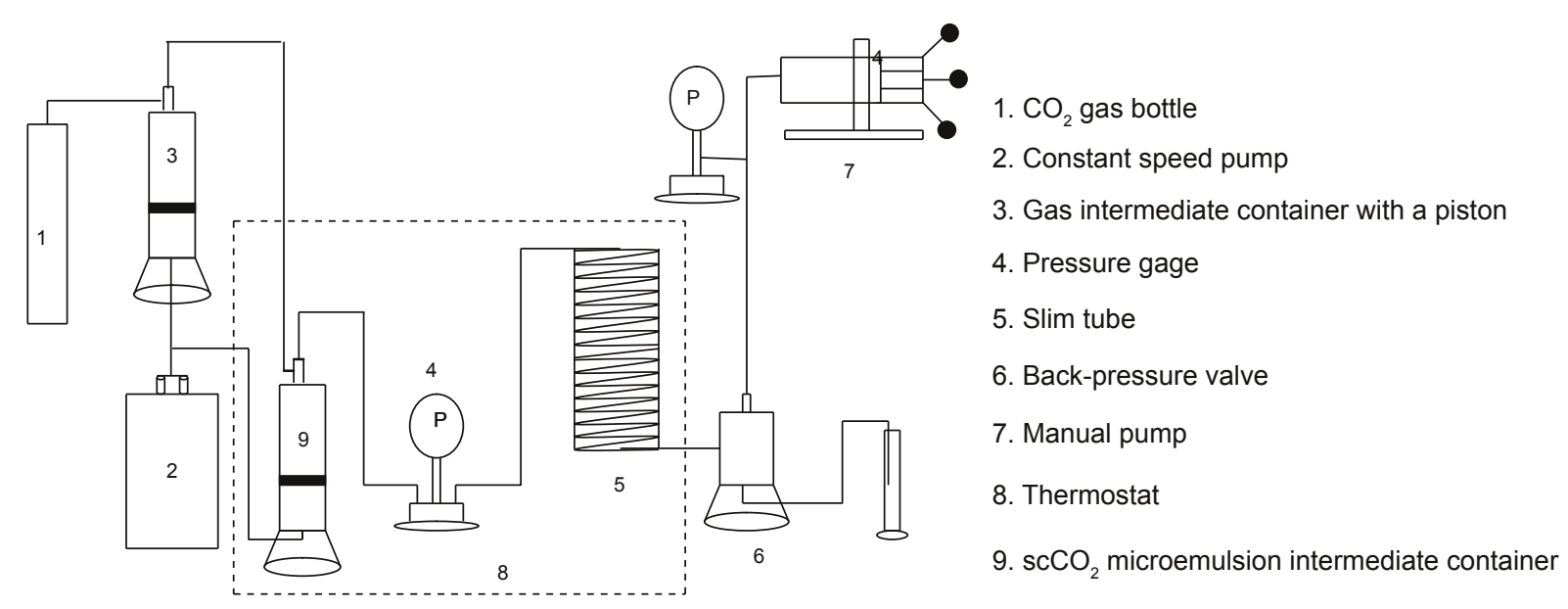

Fig. 1 The equipment for the slim tube test 
(mass percentage $13.76 \%$ ), $\mathrm{H}_{2} \mathrm{O}$ (mass percentage $0.41 \%$ $1.61 \%$ ) and $\mathrm{CO}_{2}$ (mass percentage $86.23 \%$ ) were added in $\mathrm{scCO}_{2}$ microemulsion intermediate container and the pressure was set above $8 \mathrm{MPa}$. There was also a stirrer in the container to assist the formation of the microemulsion. After the $\mathrm{scCO}_{2}$ microemulsion was formed, it was injected into the slim tube under a specified pressure.

\section{Results and discussion}

\subsection{Formation of the $\mathrm{C}_{2} \mathrm{H}_{5} \mathrm{OH} / \mathrm{scCO}_{2}$ microemulsion}

The initial conditions for preparing the $\mathrm{scCO}_{2}$ microemulsion were as follows: the volume of the visualization PVT cell was set to $105.6 \mathrm{~mL}$, the temperature was set at $45{ }^{\circ} \mathrm{C}$ and the final pressure was $19.0 \mathrm{MPa}$. A specified amount of AOT, $\mathrm{C}_{2} \mathrm{H}_{5} \mathrm{OH}$ (mass percentage $13.76 \%), \mathrm{H}_{2} \mathrm{O}$ and $\mathrm{CO}_{2}$ was added. Then the piston of the PVT cell was pushed to increase the pressure of the system up to $19.0 \mathrm{MPa}$. The transparent and homogeneous phases of the fluid would be formed which could be observed in the visualization PVT cell (Fig. 2).

Fig. 2 indicated that when the pressure was $3 \mathrm{MPa}$, the system containing $\mathrm{CO}_{2}, \mathrm{AOT}, \mathrm{H}_{2} \mathrm{O}$ and $\mathrm{C}_{2} \mathrm{H}_{5} \mathrm{OH}$ was heterogeneous at $45^{\circ} \mathrm{C}$. It can be seen that there were two phases in the system. This indicated that the system of $\mathrm{CO}_{2}$, AOT, $\mathrm{H}_{2} \mathrm{O}$, and $\mathrm{C}_{2} \mathrm{H}_{5} \mathrm{OH}$ would not form a microemulsion

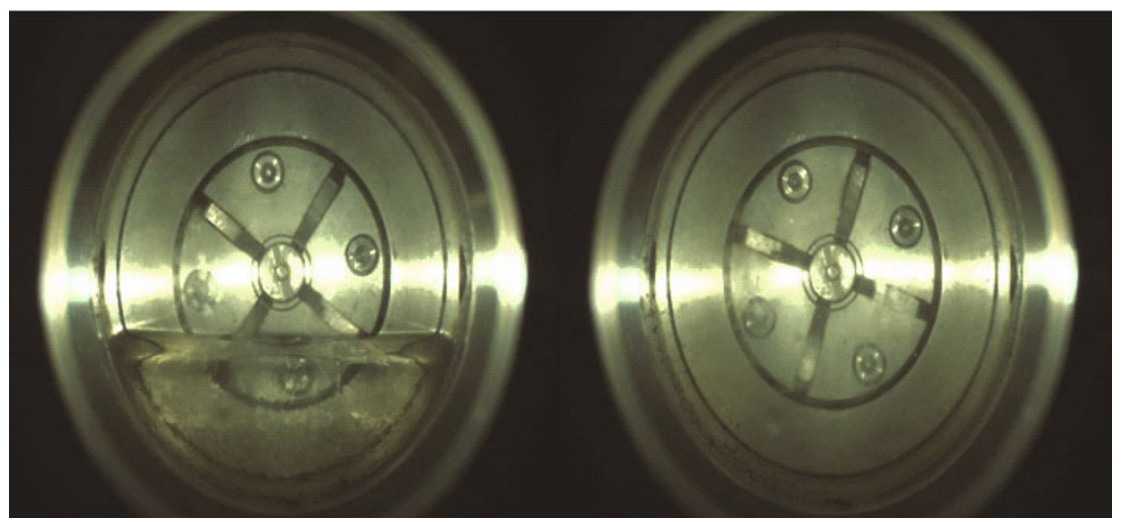

(a) Heterogeneous (3.0 MPa)

(b) Homogeneous (19.0 MPa)

Fig. 2 The phase transition of supercritical $\mathrm{CO}_{2}$ microemulsion

at $45{ }^{\circ} \mathrm{C}$. When the pressure was 19.0 $\mathrm{MPa}$, a transparent and homogeneous phase was observed in the PVT cell at 45 ${ }^{\circ} \mathrm{C}$. This indicated that a stable $\mathrm{scCO}_{2}$ microemulsion was formed. Our previous research (Cui, 2009) suggested that the cloud point of the $\mathrm{scCO}_{2}$ microemulsion was $8.0 \mathrm{MPa}$ at $45{ }^{\circ} \mathrm{C}$, which indicated that the microemulsion would be formed when the pressure higher than $8.0 \mathrm{MPa}$. $\mathrm{ScCO}_{2}$ was the continuous phase of the microemulsion and $\mathrm{H}_{2} \mathrm{O}$ was the dispersed phase. Nanoscale aggregates of AOT molecules were formed in the $\mathrm{scCO}_{2}$ microemulsion. In the $\mathrm{scCO}_{2}$ phase, the oleophilic ends of AOT molecules expanded in the non-polar $\mathrm{CO}_{2}$ phase, the polar ends aggregated and formed hydrophilic inner cores, and the water molecules were solubilizing in the cores, the AOT (surfactant) and $\mathrm{C}_{2} \mathrm{H}_{5} \mathrm{OH}$ (co-surfactant molecules) were adsorbed on the interface, forming a stable interfacial film. Therefore, an $\mathrm{scCO}_{2}$ microemulsion was formed which was optically transparent and thermodynamically stable.

\subsection{Viscosity of the $\mathrm{scCO}_{2}$ microemulsion}

The fluidity of the displacing phase decreases with an increase in the viscosity and the mobility ratio of the displacing fluid to crude oil thereby decreases, so fingering of the displacing phase may be reduced and the sweep efficiency improved; consequently oil recovery is enhanced. Therefore, if the viscosity of the $\mathrm{scCO}_{2}$ microemulsion is higher than that of the $\mathrm{scCO}_{2}$ fluid, this will improve the oil recovery of $\mathrm{CO}_{2}$ flooding. The viscosities of the $\mathrm{scCO}_{2}$ fluid and the $\mathrm{scCO}_{2}$ microemulsion were measured and the results are shown in Table 1. Within the range of the experimental pressure, the viscosity of the $\mathrm{scCO}_{2}$ microemulsion was $36 \%$ $49 \%$ higher than that of the $\mathrm{scCO}_{2}$ fluid. This is beneficial to oil recovery. Table 1 also indicated that and the viscosity difference between the $\mathrm{scCO}_{2}$ microemulsion and the $\mathrm{scCO}_{2}$ fluid increased with pressure. This may be due to existence of a "micro-pool" structure; a substance structure similar to a high-molecular-weight compound dissolved in water. This structure may cause an increase in the flow resistance inside the fluid, which is indicated by the increase in the apparent viscosity. Meanwhile, the fluid was continuously compressed with increasing pressure, making the intermolecular distance decrease and the number of micelles in the unit fluid volume increase. The rise in the micelle concentration resulted in increasing bulk viscosity.

Table 1 The viscosities of the $\mathrm{scCO}_{2}$ fluid and the $\mathrm{scCO}_{2}$ microemulsion at different pressures and $45^{\circ} \mathrm{C}$

\begin{tabular}{ccccc}
\hline \multirow{2}{*}{$\begin{array}{c}\text { Pressure } \\
\mathrm{MPa}\end{array}$} & \multicolumn{2}{c}{ Viscosity, $\mathrm{mPa} \cdot \mathrm{s}$} & $\begin{array}{c}\text { Percentage } \\
\text { increase } \\
\%\end{array}$ & $\begin{array}{c}\text { Viscosity } \\
\text { difference } \\
\mathrm{mPa} \cdot \mathrm{s}\end{array}$ \\
\cline { 2 - 5 } 9.0 & 343.18 & 510.18 & 48.66 & 167.00 \\
11.0 & 485.60 & 660.62 & 36.04 & 175.02 \\
13.0 & 567.26 & 752.80 & 32.71 & 185.54 \\
15.0 & 632.51 & 879.62 & 39.13 & 247.11 \\
\hline
\end{tabular}




\subsection{Density of the $\mathrm{scCO}_{2}$ microemulsion}

The densities of the $\mathrm{scCO}_{2}$ fluid and the $\mathrm{scCO}_{2}$ microemulsion at different pressures and $45{ }^{\circ} \mathrm{C}$ are shown in Fig. 3. The density of the $\mathrm{scCO}_{2}$ microemulsion was higher than that of the $\mathrm{scCO}_{2}$ fluid at the same pressure. When the pressure was higher than $10.0 \mathrm{MPa}$, the density of the $\mathrm{scCO}_{2}$ microemulsion was $0.8036 \mathrm{~g} / \mathrm{cm}^{3}$, almost twice that of the $\mathrm{scCO}_{2}$ fluid at $0.4336 \mathrm{~g} / \mathrm{cm}^{3}$. This is mainly because of the addition of $\mathrm{C}_{2} \mathrm{H}_{5} \mathrm{OH}$, AOT and $\mathrm{H}_{2} \mathrm{O}$. The density difference between these two systems was larger when the pressure was relatively low, and the difference decreased with an increase in pressure. The density of the $\mathrm{scCO}_{2}$ microemulsion was the weighted average of all the substances in the system, meanwhile the proportion of $\mathrm{CO}_{2}$ in the system was quite high, up to $86.7 \%$. When the pressure increased, the density of $\mathrm{CO}_{2}$ increased, meanwhile the densities separately of $\mathrm{C}_{2} \mathrm{H}_{5} \mathrm{OH}$, AOT and $\mathrm{H}_{2} \mathrm{O}$ were considered to be constant. Therefore, the density difference between the $\mathrm{scCO}_{2}$ microemulsion and the $\mathrm{scCO}_{2}$ fluid decreased continually with increasing pressure.

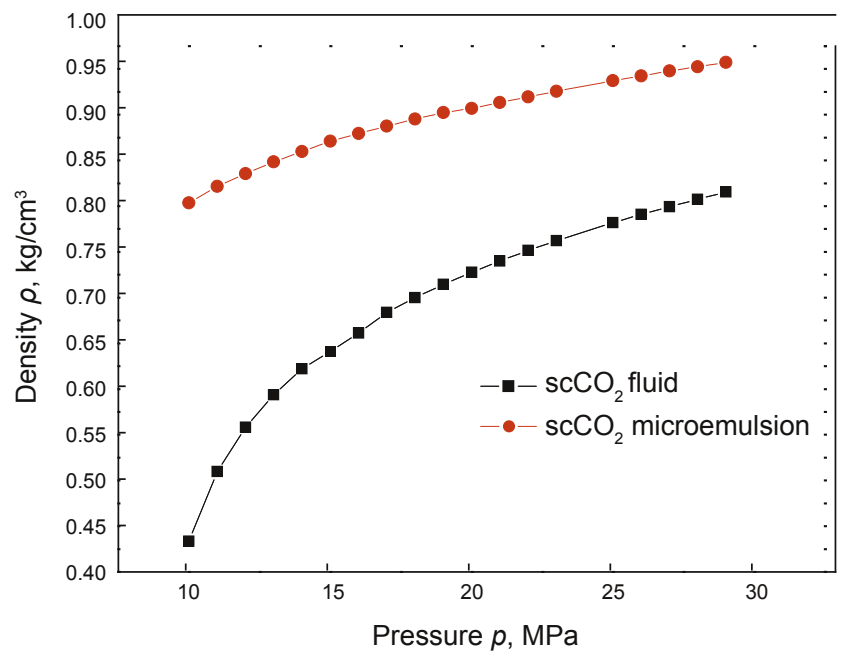

Fig.3 Density of the $\mathrm{scCO}_{2}$ microemulsion and the $\mathrm{scCO}_{2}$ fluid at $45^{\circ} \mathrm{C}$

\subsection{The MMP of the $\mathrm{scCO}_{2}$ microemulsion and Daqing crude oil}

The interfacial tension between the $\mathrm{scCO}_{2}$ microemulsion (and the $\mathrm{scCO}_{2}$ fluid) and the crude oil at $45^{\circ} \mathrm{C}$ was determined by the pendant drop method. The result is shown in Fig. 4. When $\mathrm{CO}_{2}$ was completely miscible with the crude oil, the interfacial tension between them was zero, but at this time the value of the interfacial tension could not be measured with an IFT meter and only the gradual diffusion of crude oil into the $\mathrm{CO}_{2}$ phase was observed. Therefore, the pressure at zero IFT was obtained by an extrapolation method, namely the minimum miscibility pressure (MMP). The images of the miscible phase of the $\mathrm{scCO}_{2}$ fluid/the $\mathrm{scCO}_{2}$ microemulsion with Daqing crude oil are shown in Figs. 5 and 6.

The interfacial tension between the $\mathrm{scCO}_{2}$ and the crude oil was linear with pressure. A fitting expression, $\sigma=17.92-0.73 p$, with a correlation coefficient of 0.9942 was obtained and used to describe the relationship between the interfacial tension and the pressure for the $\mathrm{scCO}_{2}$ and

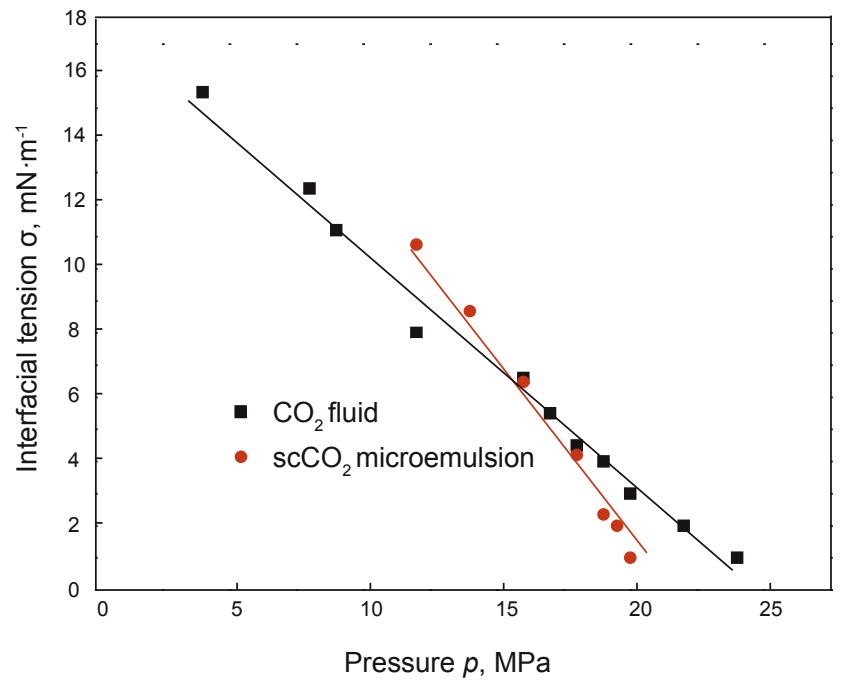

Fig. 4 The interface tension between $\mathrm{CO}_{2}$ and crude oil versus pressure

crude oil, where $\sigma$ was the interfacial tension and $p$ was the pressure. When the pressure was equal to $24.55 \mathrm{MPa}$, the interfacial tension was zero, which meant the MMP of the $\mathrm{CO}_{2}$ and crude oil was $24.55 \mathrm{MPa}$. In the experimental process, the pressure increased gradually, when the crude oil totally dissolved in the $\mathrm{CO}_{2}$ phase, it was considered that $\mathrm{CO}_{2}$ was completely miscible with crude oil; the actual measured pressure was $25.6 \mathrm{MPa}$.

Similarly, the relationship between the interfacial tension and the pressure for the $\mathrm{scCO}_{2}$ microemulsion and crude oil could be expressed as follows: $\sigma=21.08-0.96 p$ (with a correlation coefficient of 0.9890 ). The calculated MMP of the $\mathrm{scCO}_{2}$ microemulsion and crude oil was $22.02 \mathrm{MPa}$. The actual measured MMP of the $\mathrm{scCO}_{2}$ microemulsion and crude oil was $23.1 \mathrm{MPa}$. This is to say the MMP between the $\mathrm{scCO}_{2}$ microemulsion and crude oil was lower than that between $\mathrm{scCO}_{2}$ and crude oil.

The light hydrocarbon component in the crude oil is easily dissolved in the $\mathrm{CO}_{2}$ phase. When the pressure reaches a certain value, the light hydrocarbon is dissolved in the $\mathrm{CO}_{2}$, and then the content of the light hydrocarbon in the $\mathrm{CO}_{2}$ phase increases, which gives the $\mathrm{CO}_{2}$ some properties of a rich gas; as a result it is easier for $\mathrm{CO}_{2}$ to become miscible with crude oil. For the $\mathrm{scCO}_{2}$ microemulsion, AOT (surfactant) and $\mathrm{C}_{2} \mathrm{H}_{5} \mathrm{OH}$ (co-surfactant) dissolved in the $\mathrm{CO}_{2}$ phase are conducive to reducing the interfacial tension between $\mathrm{CO}_{2}$ and crude oil, thereby making the light and heavy hydrocarbon components of crude oil miscible with $\mathrm{scCO}_{2}$. Consequently the MMP of the $\mathrm{scCO}_{2}$ microemulsion and crude oil decreases significantly.

The oil recoveries of $\mathrm{scCO}_{2}$ flooding and $\mathrm{scCO}_{2}$ microemulsion flooding were measured separately with slim tube tests. The results are shown in Fig. 7. In $\mathrm{CO}_{2}$ flooding, if the oil recovery reaches $80 \%$ at gas breakthrough or the final oil recovery reaches $90 \%$, the flooding pattern is considered miscible (Yang, 1998). The final oil recovery increased with increasing pressure, but the rate of increase of recovery was quite slow when the pressure was higher than the MMP. Therefore, the MMP may be determined by the relation between oil recovery and pressure, which means that the 


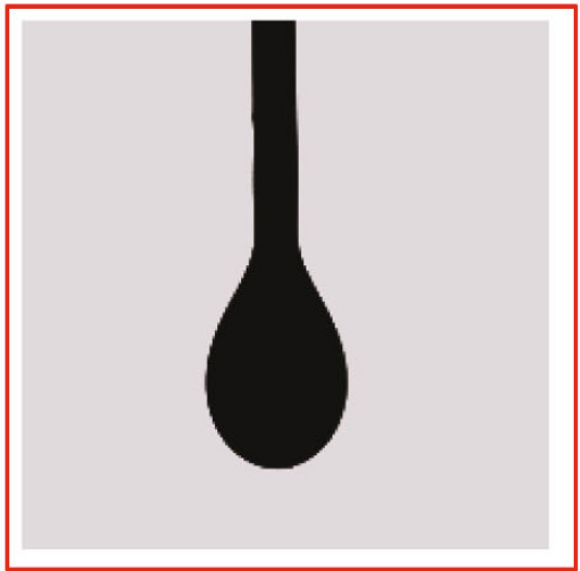

(a) $6.2 \mathrm{MPa}$

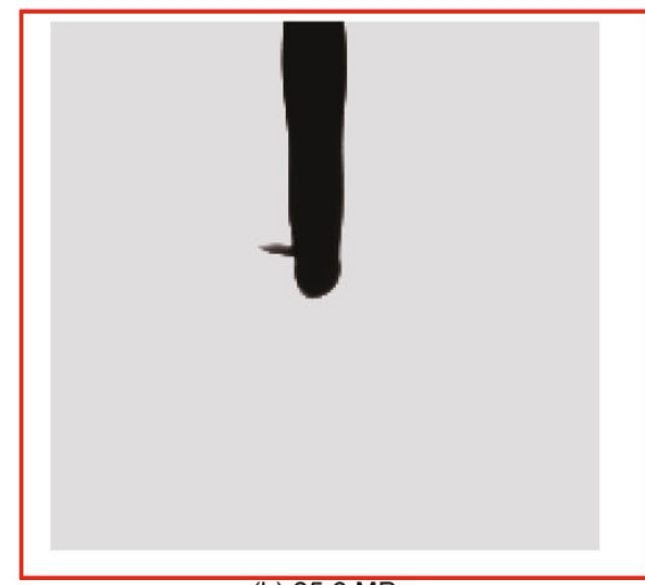

(b) $25.6 \mathrm{MPa}$

Fig. 5 Images of oil drops in the $\mathrm{scCO}_{2}$ fluid at $45^{\circ} \mathrm{C}$

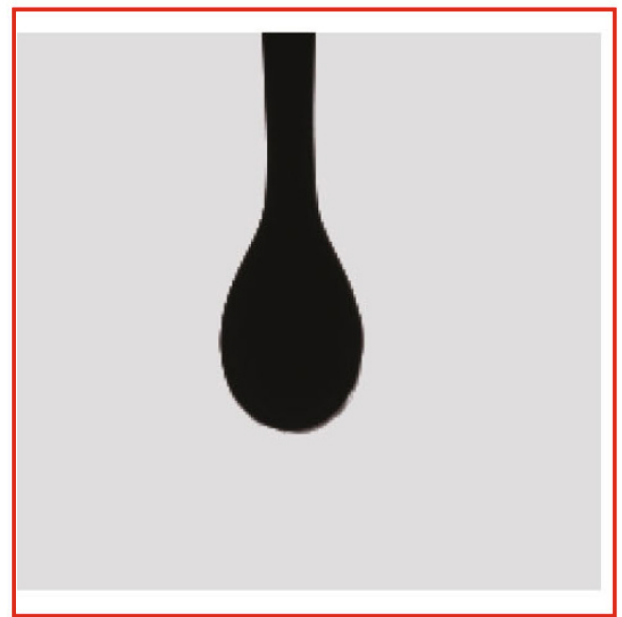

(a) $12 \mathrm{MPa}$

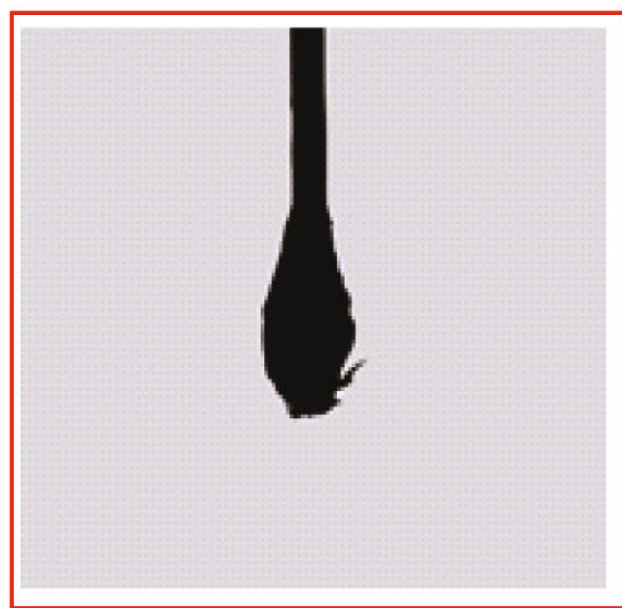

(b) $23.1 \mathrm{MPa}$

Fig. 6 Images of oil drops in the supercritical $\mathrm{CO}_{2}$ microemulsion at $45^{\circ} \mathrm{C}$

miscible conditions could be determined by analyzing the turning point in the recovery curve. When the pressure was lower than that of the turning point, the oil recovery increased sharply with pressure, but when the pressure was higher than the turning point, there was a slight change of oil recovery and the curve of oil recovery versus pressure was nearly horizontal. Fig. 7 indicated that when the temperature was 45 ${ }^{\circ} \mathrm{C}$, the MMP for $\mathrm{CO}_{2}$ flooding was $23.8 \mathrm{MPa}$; for the $\mathrm{scCO}_{2}$ microemulsion flooding, it was $22.7 \mathrm{MPa}$. This is to say the MMP of the $\mathrm{scCO}_{2}$ microemulsion and crude oil was lower than that of the $\mathrm{scCO}_{2}$ and oil.

\subsection{Mechanism of $\mathrm{seCO}_{2}$ microemulsion for enhancing oil recovery}

The results of slim tube tests showed that the oil recovery of the $\mathrm{scCO}_{2}$ microemulsion flooding was higher than that of the $\mathrm{scCO}_{2}$ flooding at the same pressure. Except for the lower interfacial tension between the $\mathrm{scCO}_{2}$ microemulsion and crude oil, the viscosity of the $\mathrm{scCO}_{2}$ microemulsion was significantly higher than the $\mathrm{scCO}_{2}$ fluid. The fluidity of the displaced phase (oil) is not changed, so the mobility ratio of the displacing phase to the displaced phase decreases, and the relative flow rate also decreases. Therefore, the area swept by the displacing phase increases before breakthrough and the oil recovery is enhanced. In addition, the density of the $\mathrm{scCO}_{2}$ microemulsion is higher than that of the $\mathrm{scCO}_{2}$ fluid; this may prevent fluid overlap and reduce viscous fingering, and delay and minimize the potential for fluid breakthrough.

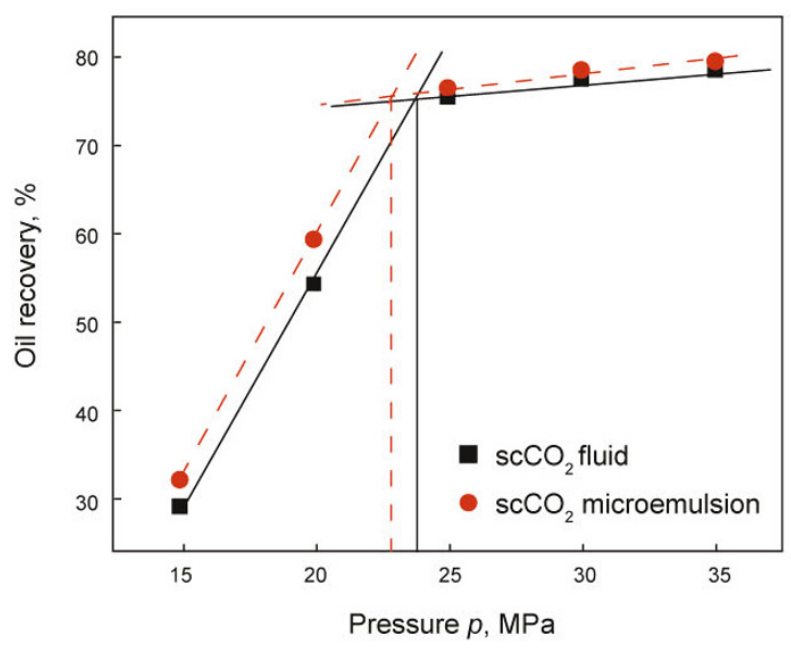

Fig. 7 Oil recovery at different pressures and $45^{\circ} \mathrm{C}$ 


\section{Conclusions}

1) Based on the pendant drop method, the miscibility minimum pressure (MMP) of $\mathrm{scCO}_{2}$ and Daqing crude oil was $24.55 \mathrm{MPa}$ at $45{ }^{\circ} \mathrm{C}$, and the MMP of the $\mathrm{scCO}_{2}$ microemulsion and Daqing crude oil was $22.02 \mathrm{MPa}$. Based on the slim tube tests, the MMP of $\mathrm{scCO}_{2}$ and Daqing crude oil was $23.8 \mathrm{MPa}$ at $45{ }^{\circ} \mathrm{C}$, and the MMP of the $\mathrm{scCO}_{2}$ microemulsion and Daqing crude oil was $22.7 \mathrm{MPa}$. The MMP significantly decreased for the $\mathrm{scCO}_{2}$ microemulsion compared with $\mathrm{scCO}_{2}$.

2) The density and viscosity of the $\mathrm{scCO}_{2}$ microemulsion were both higher than those of the $\mathrm{scCO}_{2}$ fluid, and the MMP with crude oil was lower. The $\mathrm{scCO}_{2}$ microemulsion could not only improve the sweep efficiency, but also decrease the MMP, thereby achieving higher oil recovery by $\mathrm{scCO}_{2}$ microemulsion flooding compared with $\mathrm{CO}_{2}$ flooding.

\section{Acknowledgements}

The authors are grateful for financial support from the National Natural Science Fund (50904073) and the CNPC Science and Technology Innovation Fund (2008D-5006-0206).

\section{References}

Bon $\mathrm{J}$ and Sarma $\mathrm{H}$ K. An investigation of minimum miscibility pressure for $\mathrm{CO}_{2}$-rich injection gases with pentanes-plus fraction. Paper SPE 97536 presented at SPE International Improved Oil Recovery Conference in Asia Pacific, 5-6 December 2005, Kuala Lumpur, Malaysia

Chattopadhyay P and Gupta R B. Production of antibiotic nanoparticles using supercritical $\mathrm{CO}_{2}$ as antisolvent with enhanced mass transfer. Industrial and Engineering Chemistry Research. 2001. 40: 35303539

Christensen J R, Stenby E H and Skauge A. Review of WAG field experience. Paper SPE 39883 presented at the International Petroleum Conference and Exhibition of Mexico, 3-5 March 1998, Villahermosa, Mexico

Cui B. Research of the Minimum Miscibility Pressure of Supercritical Carbon Dioxide Microemulsion. MS Thesis. China University of Petroleum, Beijing. 2010 (in Chinese)

Eastoe J, Bayazit Z, Martel S, et al. Droplet structure in a water in $\mathrm{CO}_{2}$ microemulsion. Langmuir. 1996. 12(2): 1423-1430

Eckert C A, Knutson B L and Debenedetti P G. Supercritical fluid as solvents for chemical and materials processing. Nature. 1996. 383, 313-318

Grigg R B and Siagian U W R. Understanding and exploiting four-phase flow in low-temperature $\mathrm{CO}_{2}$ floods. Paper SPE 39790 presented at SPE Permian Basin Oil and Gas Recovery Conference, 23-26 March 1998, Midland, Texas

Heitz M P, Carlier C, DeGrazia J, et al. Water core in perfluoropolyether based microemulsion formed in supercritical carbon dioxide. Journal of Physical Chemistry: B. 1997. 101(5): 6707-6713

Holmes J D, Bhargava P A, Korgel B A, et al. Synthesis of cadmium sulfide Q particles in water-in- $\mathrm{CO}_{2}$ microemulsions. Langmuir. 1999. 15(20): 6613-6615

Hutton B H, Perera J M, Grieser F, et al. Investigation of AOT reverse microemulsions in supercritical carbon dioxide. Colloids and Surfaces A: Physicochemical and Engineering Aspects. 1999. 146(3): $227-241$
Kalogiannis C G, Eleni P and Panayiotou C G. Production of amoxicillin microparticles by supercritical antisolvent precipitation. Industrial and Engineering Chemistry Research. 2005. 44: 9339-9346

Kane M A, Baker G A, Pandey S and Bright F V. Performance of cholesterol oxidase sequestered within reverse micelles formed in supercritical carbon dioxide. Langmuir. 2000. 16(11): 4901-4905

Kikic I, Lora M and Bertucco A. Thermodynamic analysis of threephase equilibria in binary and ternary systems for applications in rapid expansion of a supercritical solution (RESS), particles from gas saturated solutions (PGSS) and supercritical antisolvent crystallization (SAS). Industrial and Engineering Chemistry Research. 1997. 36: 5507-5515

Langston M V, Hoadlej S F and Young D N. Definitive $\mathrm{CO}_{2}$ flooding response in the SACROC Unit. Paper SPE 17321 presented at SPE Enhanced Oil Recovery Symposium, 16-21 April 2003, Tulsa, Oklahoma

Liu J C, Han B X, Li G Z, et al. Investigation of nonionic surfactant Dynol-604 based reverse microemulsions formed in supercritical carbon dioxide. Langmuir. 2001. 17(26): 8040-8043

Luo D L, Qiu T Q and Lu Q. Supercritical carbon dioxide inverse-phase microemulsions. Fine Chemicals. 2005. 22(5): 342-347 (in Chinese)

Matson D W, Fulton J L, Petersen R C, et al. Rapid expansion of supercritical fluid solutions: Solute formation of powders, thin film and fibers. Industrial and Engineering Chemistry Research. 1987. 26: 2298-2306

Ohde $\mathrm{M}$, Ohde $\mathrm{H}$ and Wai C M. Recycling nanoparticles stabilized in water-in- $\mathrm{CO}_{2}$ microemulsions for catalytic hydrogenations. Langmuir. 2005. 21(5): 1738-1744

Roper Jr. M K, Pope G A and Sepehrnoori K. Analysis of tertiary injectivity of carbon dioxide. Paper SPE 23974 presented at Permian Basin Oil and Gas Recovery Conference, 18-20 March 1992, Midland, Texas

Shen P P and Yang Y Z. Problems on enhanced oil recovery by using greenhouse gas. China Basic Science. 2006. 30(3): 23-31 (in Chinese)

Sun Y P, Atorngitjawat P and Meziani M J. Preparation of silver nanoparticles via rapid expansion of water in carbon dioxide microemulsion into reductant solution. Langmuir. 2001. 17(19): 5707-5710

Yang Z J. Mechanism study of miscible displacement and its application prospect. Oil \& Gas Recovery Technology. 1998. 5(1): 69-74 (in Chinese)

Yu J L, Wang S J and Tian Y L. Experimental determination and calculation of thermodynamic properties of $\mathrm{CO}_{2}+$ octane to high temperatures and high pressures. Fluid Phase Equilibria. 2006. 246: 6-14

Yuan H, Johns R T and Egwuenu A M. Improved MMP correlations for $\mathrm{CO}_{2}$ floods using analytical gas flooding theory. Paper SPE 89359 presented at Symposium on Improved Oil Recovery, 17-21 April 2004, Tulsa, Oklahoma

Zhang J L and Han B X. Supercritical $\mathrm{CO}_{2}$-continuous microemulsion and compressed $\mathrm{CO}_{2}$-expanded reverse microemulsion. Journal of Supercritical Fluid. 2009. 3(47): 531-536

Zhao Y C, Song Y C, Liu Y, et al. Visualization of $\mathrm{CO}_{2}$ and oil immiscible and miscible flow processes in porous media using NMR micro-imaging. Petroleum Science. 2011. 8(2): 183-193

Zhu Z Q and $\mathrm{Xu} \mathrm{X}$. Chemical Engineering Thermodynamic. Beijing: Chemical Industry Press. 2006. 261-262 (in Chinese)

Zielinski R G, Kline S R and Kaler E W. A small-angle neutron scattering study of water in carbon dioxide microemulsions. Langmuir. 1997. 13(15): 3934-3937 